of an animal, and pumps oxygenated defibrinated blood round an artificial circuit, which may include one or more different organs: the latter are thus perfused with blood under conditions approximating the normal. The preparation, however, only lasts for a few hours. It is reported in The Times of June 22 that Dr. Alexis Carrel and Colonel C. A. Lindbergh, the well-known American airman, have devised, at the Rockefeller Institute for Medical Research, New York, an apparatus by means of which isolated organs can be kept alive, even growing, for prolonged periods.

Is this apparatus, the organs are removed aseptically from the dead animal together with surrounding tissues, arteries, veins, nerves and lymph vessels : all are kept constantly protected with gauze pads soaked in Dakin's solution. The perfusion fluid consists of blood serum or of solutions containing protein-split products : a small amount of phenol red is added to act as an indicator of the metabolic activity of the organ or of the occurrence of bacterial infection. The air supply, kept in contact with the perfusion fluid, contains 40 per cent oxygen and 3-4 per cent carbon dioxide. The apparatus is kept in an incubator at body temperature. The organs so far kept alive in this manner have included thyroid gland, ovary, adrenal, spleen, heart and kidney, obtained from adult fowls or cats ; an ovary actually grew in size and weight by the addition of now cells and tissues. It is hoped to use the method for the study of the production of hormones by the glands of internal secretion, for the isolation of substances essential to the growth, differentiation and functional activity of these glands and for the discovery of the laws of association of organs. It is also hoped to study diseases in isolated human organs. The success of the method depends principally upon maintaining complete freedom from bacterial infection, and secondly on the use of suitable nutrient fluids, difficulties which Carrel and Lindbergh appear to have overcome.

\section{Antiquities from Tell Duweir, Palestine, 1934-35}

THE annual exhibition of antiquities from Tell Duweir (Lachish), Palestine, found by the Wellcome Archæological Research Expedition to the Near East under the leadership of Mr. J. L. Starkey in the course of the excavations of 1934-35, opened on June 24 at the Wellcome Research Institution, 183-193 Euston Road, London, N.W.1. The objects exhibited again illustrate details of culture in the various periods represented on the site, beginning with the extensive prehistoric settlements of the copper and bronze ages and ending with the later Jewish kingdom, when the city suffered the successive onslaughts of Sennacherib and Nebuchadnezzar. Further light is thrown upon the early cave dwellers, and the possible line of development of the localised art reminiscent of Tell el-Amarna, of which evidence was found last year, is suggested by a bone inlay in the form of a head, which seems to be a copy of an ivory original. Another interesting find is an Iron Age burial, which included among its grave furniture a short-handled iron fork with three long prongs. It is reasonable to conjecture that this implement served the priest to extract joints from the offeringsbin of the sanctuary discovered last year. Culturally and historically, however, the outstanding finds are a further example of the early script, resembling that from Sinai, which adds three characters to those known from last year's find, and a series of letters on ostraka, dating from shortly before the fall of the city, now to be identified with certainty as Lachish. This discovery, long eagerly awaited, alone makes the excavation notable. An instructive commentary on the work of the expedition is afforded by a cast of the bas-relief of the siege of Lachish, now in the British Museum, which, coloured and skilfully flood-lit, can be seen in full detail for the first time. The exhibition is open daily from 11 a.m. until 5 p.m., and on certain evenings until 8 p.m., until July 27. A lecture on "The Lachish Letters found at Tell Duweir" will be given by Dr. Harry Torczyner, professor of Hebrew philology in the University of Jerusalem, on Tuesday, July 9 at 5 p.m. Admission to the exhibition and lecture is free by ticket.

\section{The Quetta Earthquake}

A Corresponden's of The Times (June 24) gives some interesting details about the great earthquake of May 31. The zone of destruction extends from Surab in Kalat State to a few miles north of Quetta. Its length is 130 miles and its width $15-20$ miles. Even within this area, its effects were variable. In some parts, they spread over the whole width; in others, they were confined to a narrow line, some villages being untouched, while others were destroyed. Quetta lies in an upland valley, 5,500 ft. above the sea, in which earthquakes are rather frequent. The recent shock, however, differed from its predecessors. Though the loss of life was much greater, road and rail communications were not damaged, trees, lamp. posts and most of the telegraph poles remained standing, and electric current was available from the first hour of the shock. The great destruction in Quetta City is traced to the poor quality of the buildings, the erection of earthquake-proof houses having been generally neglected. In the areas of excessive damage, the few buildings that were earthquake-proof remained intact, and not even their chimneys fell.

\section{Tercentenary of the Muséum National d'Histoire Naturelle}

The tercentenary of the Muséum National d'Histoire Naturelle in Paris has been celebrated during the past week, and included a séance solennelle on June 25 in the presence of the President of the Republic. Sir Arthur Hill, director of the Royal Botanic Gardens, Kew, was the principal delegate from Great Britain, and delivered an address in the name of the foreign delegates who were present. In view of the number of delegations attending the gathering, it was decided to select representative men of science to deliver addresses; Sir Arthur Hill spoke on behalf of the foreign delegates and also as a botanist ; 